\title{
EFEKTIVITAS MANAJEMEN KELAS UNTUK MENURUNKAN GANGGUAN KONSENTRASI BELAJAR MATEMATIKA PADA SISWA SD
}

\author{
Rifka Retno Annisa, Wiwien Dinar Pratisti dan Zahrotul Uyun \\ Fakultas Psikologi, Universitas Muhammadiyah Surakarta \\ Email: rifkarannisa@gmail.com
}

Diserahkan 14 Mei 2019; Diterima 14 Juli 2019; Dipublikasikan 01 Agustus 2019

\begin{abstract}
ABSTRAK
Gangguan konsentrasi belajar matematika rentan terjadi pada berbagai jenjang pendidikan dan mengakibatkan terhambatnya proses belajar mengajar serta mempengaruhi prestasi akademik siswa. Dalam upaya mengatasi gangguan konsentrasi belajar matematika siswa, guru perlu memiliki strategi khusus agar dapat meminimalisir hambatan dalam proses belajar mengajar yang dapat menganggu konsentrasi belajar matematika siswa, strategi yang diterapkan guru tidak terlepas dari kemampuan guru dalam memanajemen kelas. Untuk itu, penelitian ini bertujuan menguji efektivitas manajemen kelas untuk menurunkan gangguan konsentrasi belajar matematika pada siswa SD. Manajemen kelas terdiri dari tiga tahapan meliputi preventif, active learning dan korektif. Manajemen kelas diterapkan pada 30 orang siswa yang berada dalam satu kelas yang dipilih dengan teknik purposive sampling. Rancangan penelitian menggunakan nonrandomized control group pretest-posttest design dan data dikumpulkan dengan skala gangguan konsentrasi belajar matematika. Hasil analisis data menunjukkan bahwa intervensi manajemen kelas efektif menurunkan gangguan konsentrasi belajar matematika.
\end{abstract}

Kata kunci: gangguan konsentrasi belajar matematika; manajemen kelas.

\section{CLASSROOM MANAGEMENT EFFECTIVENESS TO REDUCE METHEMATICS LEARNING CONCENTRATION DISORDER AT STUDENTS SD MUHAMMADIYAH 4 KANDANGSAPI SURAKARTA}

\begin{abstract}
Mathematics learning concentration disorder are prone to occur at various levels of education and resulted in the inhibition of teaching and learning processes and influence student academic achievement. In an effort to overcome mathematics learning concentration disorder, teachers need to have a specific strategy in order to minimize barriers in the teaching and learning process which can disrupt the concentration of students' mathematics learning. Tthe strategies applied by the teacher are inseparable from the teacher's ability to manage the class. For this reason, this study aims to test the effectiveness of class management to reduce the disruption of mathematics learning concentration in elementary school students. Classroom management consists of three stages including preventive, active learning and corrective. Classroom management is applied to 30 students who are in one class selected by purposive sampling technique. The design of the study used a nonrandomized control group pretest-posttest design and data were collected with mathematics learning concentration disorder scale. The results of data analysis showed that classroom management interventions effectively reduced the mathematics learning concentration disorder.
\end{abstract}

Keywords: mathematics learning concentration disorder; classroom management. 


\section{PENDAHULUAN}

Menurut Hatiningsih (2013) konsentrasi belajar adalah satu dari indikator yang dipercaya mampu mempermudah siswa untuk meraih tujuan belajarnya. Konsentrasi belajar adalah bagian penting yang semestinya dipunyai oleh setiap siswa karena dengan konsentrasi siswa mampu fokus dan memahami pelajaran yang diberikan dengan menyampingkan halhal di luar pelajaran. Namun tidak semua siswa dapat berkonsentrasi saat belajar, kondisi siswa yang tidak dapat berkonsentrasi saat belajar dapat dikatakan sebagai siswa yang memiliki konsentrasi belajar rendah. Menurut Fieldman (2002) konsentrasi belajar rendah dapat disebut sebagai gangguan konsentrasi belajar. Siswa yang mengalami gangguan konsentrasi belajar cenderung sulit menangkap informasi dan instruksi yang disampaikan guru saat kegiatan belajar mengajar sehingga peluang siswa untuk dapat menerima dan memahami informasi serta instruksi menjadi lebih kecil.

Ada banyak hal yang menyebabkan gangguan konsentrasi belajar pada siswa, salah satunya adalah karena pelajaran yang diterima terlalu sulit. Diantara banyaknya pelajaran yang dianggap sulit dan cenderung dihindari oleh siswasalah satunya adalah pelajaran matematika. Chyquitita, Winardi \& Hidayat (2018) mengatakan bahwa matematika adalah salah satu pelajaran sulit yang menyebabkan konsentrasi belajar siswa terganggu karena otak menjadi lelah dan tegang. Kelelahan dan ketegangan pada otak menyebabkan siswa stres dan akhirnya kehilangan konsentrasi belajar. Sepanjang tahun 2010-2015 terdapat berbagai kasus gangguan konsentrasi belajar pada siswa diberbagai jenjang pendidikan diantaranya penelitian Purwanto \& Nuryana (2010) di SD Negeri Serengan I Surakarta, penelitian Mulyana, Izzati \& Rahmasari (2013) di SMK Wachid Hasyim Surabaya dan penelitian Kamil \& Olvatika (2015) di SMPN 1 Hulu Sungkai Kab. Lampung Utara menunjukkan adanya permasalahan serupa yaitu gangguan konsentrasi belajar. American Pshcyatric Association (APA) tahun 2013 menyebutkan adanya angka kejadian gangguan konsentrasi belajar dengan atau tanpa hiperaktivitas adalah sebesar 1-20\% pada anak usia sekolah. Sebuah studi pada jurnal Psychological Medicine juga menyatakan bahwa salah satu masalah yang sering dialami anak adalah gangguan konsentrasi belajar. Hal ini berdampak pada sulitnya potensi anak berkembang dengan maksimal di sekolah, (Kompas.com, 2018).

Fakta di lapangan menunjukkan adanya fenomena gangguan konsentrasi belajar matematika pada siswa-siswa di SD Muhammadiyah 4 Kandangsapi Surakarta. Gangguan konsentrasi belajar matematika pada siswa di sekolah ini cukup memprihatinkan, bukan hanya berdampak pada tidak optimalnya siswa dalam menyerap materi pelajaran tetapi juga pada kegagalan siswa mengerjakan latihan soal, kuis maupun ulangan dan mengakibatkan nilai matematika siswa kurang memuaskan bahkan sebagian besar siswa diharuskan mengikuti remedial.

Gangguan konsentrasi belajar matematika adalah kondisi dimana individu tidak mampu untuk memfokuskan dan menjaga pikiran terhadap apapun yang berhubungan dengan objek-objek dalam pelajaran matematika. Salah satu alasan mengapa siswa harus berkonsentrasi pada pelajaran matematika adalah karena untuk dapat memahami rumus dan menjawab soal-soal dengan cepat dan tepat, siswa tidak boleh kehilangan sedikitpun momentum saat guru menjelaskan. Sebab, jika ada bagian yang terlewat atau luput dari perhatian maka pada bagian-bagian selanjutnya siswa tidak akan dapat memahaminya lagi. Dalam penelitian ini, gangguan konsentrasi belajar matematika pada siswa akan diturunkan dengan intervensi manajemen kelas.

Dalam penelitian ini, pelaksanaan intervensi manajemen kelas dilakukan dalam tiga prosedur yaitu (1) preventif, (2) active learning dan (3) korektif. Manajemen kelas dengan kegiatan preventif bertujuan untuk mengantisipasi munculnya suasana tidak kondusif diawal berlangsungnya kegiatan belajar mengajar. Menurut Arikunto (2000) aktivitas belajar mengajar yang dimulai dengan tertib dan teratur memungkinkan siswa-siswa menjadi lebih mudah berkonsentrasi dalam menerima pelajaran. Selanjutnya yaitu manajemen kelas dengan metode active learning dimaksudkan untuk memudahkan guru dalam mengelola dan menyampaikan materi pelajaran agar siswa dapat berpartisipasi aktif dalam setiap proses pembelajaran dan tidak menjadikan guru sebagai satusatunya sumber informasi.

Menurut Brophy (2006), Doyle (1990), Emmer \& Evertson (1991) dalam buku yang ditulis Ormrod berjudul Educational Psychology Developing Learners (2008), metode active learning dalam manajemen kelas efektif mengatasi gangguan konsentrasi belajar siswa, dengan metode active learning ini siswa akan lebih aktif dan produktif dalam setiap proses pembelajaran sehingga akan mengecilkan dan meminimalisir peluang siswa untuk mengerjakan hal-hal diluar kegiatan belajar.

Bagian terakhir yaitu manajemen kelas dengan kegiatan korektif bertujuan untuk mengelola sistem pembelajaran agar dapat terselenggara kegiatan belajar mengajar yang efisien dan produktif dimana guru dapat mengajar dengan efisien dan siswa dapat mengikuti proses pembelajaran tanpa adanya kebingungan ataupun hambatan. Tindak lanjut terhadap kebingungan ataupun hambatan yang termanistasi dalam perilaku baik / buruk siswa dilakukan dengan menerapkan sistem reward dan punishment, sistem ini diberlakukan sebagai bentuk apresiasi dengan konsekuensi positif maupun negatif terhadap perilaku siswa. Menurut Ormrod (2008) sistem reward dan punishment efektif mendorong dan memotivasi siswa dalam memunculkan atau menghilangkan perilaku tertentu sesuai dengan 
konsekuensi yang diterimanya sebagai stimulus yang menguatkan atau melemahkan perilaku.

Hasil penelitian-penelitian sebelumnya menunjukkan bahwa manajemen kelas terbukti dapat meningkatkan minat belajar, efektifvitas pembelajaran, perilaku belajar, motivasi belajar, hasil belajar dan aktivitas belajar siswa. Berdasarkan pemaparan berbagai hasil penelitian terdahulu, peneliti tertarik untuk mengkaji lebih dalam mengenai manajemen kelas dan gangguan konsentrasi belajar siswa khususnya pada pembelajaran matematika. Hipotesis yang diajukan dalam penelitian ini adalah manajemen kelas efektif menurunkan gangguan konsentrasi belajar matematika siswa.

\section{METODE}

Penelitian ini dilakukan dengan menggunakan rancangan kuasi eksperimen dengan nonrandomized control group pretest-posttest design. Pemilihan subjek penelitian dilakukan dengan teknik purposive sampling yang merupakan pengambilan sampel secara sengaja sesuai dengan kriteria sampel yang diinginkan. Adapun kriteria yang harus dipenuhi (1) merupakan kelas dengan gangguan konsentrasi belajar matematika yang paling perlu ditangani. (2) merupakan siswa berusia 912 tahun. (3) berada dalam satu kelas yang sama. Dari total empat kelas yang diperoleh dari rekomendasi awal pihak sekolah, siswa-siswa yang kelasnya memenuhi kriteria yaitu kelas VA dan VB yang pada masingmasing kelas berjumlah 30 siswa. Kedua kelas ini terpilih setelah melalui tahap screening berdasarkan hasil rekomendasi guru dengan metode observasi, wawancara dan dokumen catatan pada pelajaran matematika serta dikroscek kesesuaiannya dengan hasil angket gangguan konsentrasi belajar matematika.

Pengukuran gangguan konsentrasi belajar matematika siswa menggunakan skala gangguan konsentrasi belajar matematika yang disusun sendiri oleh peneliti berdasarkan aspek-aspek konsentrasi belajar menurut Piaget (1972) yaitu 1) aspek kognitif, ialah kecenderungan perilaku individu yang mengarah pada pemerolehan pengetahuan, informasi dan kecakapan intelektual. 2) aspek afektif ialah kecenderungan perilaku individu yang mengarah pada nilai-nilai, sikap, emosi, penghargaan, perasaan, semangat dan minat terhadap sebagian atau seluruh aspek-aspek yang terdapat dalam kegiatan pembelajaran dan 3) psikomotorik ialah kecenderungan perilaku individu yang mengarah pada aktivitas fisik yang terkoordinasi atau keterampilan untuk mengerjakan sesuatu. Kemudian skala diberi penilaian oleh sembilan orang ahli dan diuji cobakan kepada 163 orang siswa yang memiliki karakteristik serupa dengan subjek penelitian. Hasil uji reliabilitas menunjukkan nilai Cronbach's $\alpha$ sebesar 0,886. Menurut Ghozali (2006) sebuah skala dinyatakan reliabel jika Cronbach's $\alpha$ mendekati angka 1,00. Dengan demikian, skala gangguan konsentrasi belajar matematika ini dinyatakan reliabel dan layak digunakan dalam penelitian. Skor gangguan konsentrasi belajar matematika diperoleh dari skor total seluruh aspek dari skala gangguan konsentrasi belajar matematika yang menunjukkan gangguan konsentrasi belajar matematika siswa. Semakin tinggi skor total yang diperoleh maka semakin tinggi gangguan konsentrasi belajar matematika siswa. Berdasarkan screening dengan hasil rekomendasi guru menggunakan metode observasi, wawancara dan dokumen catatan pada pelajaran matematika serta dikroscek kesesuaiannya dengan angket gangguan konsentrasi belajar matematika, dua dari empat kelas tidak diikutsertakan dalam penelitian karena tidak direkomendasikan guru sebagai kelas dengan gangguan konsentrasi belajar matematika paling perlu ditangani dan memiliki skor gangguan konsentrasi belajar matematika rendah berdasarkan pengisian angket sehingga tidak memenuhi kriteria yang telah ditentukan dalam penelitian ini.

Kedua kelas yang memenuhi kriteria kemudian dibagi menjadi dua kelompok yaitu kelompok kontrol (KK) dan kelompok eksperimen (KE) dan masing-masing akan diberikan pretestposttest dan follow up. KE diberikan perlakuan berupa intervensi manajemen kelas sedangkan KK tidak diberi perlakuan dan masuk pada daftar tunggu. Rancangan penelitian dapat dilihat pada Tabel 1.

Tabel 1. Rancangan Penelitian

\begin{tabular}{ccccc}
\hline Kelompok & Pre Test & Perlakuan & Post Test & Follow up \\
\hline $\mathrm{KE}$ & $\mathrm{A} 1$ & $\mathrm{X}$ & $\mathrm{A}_{2}$ & $\mathrm{~A}_{3}$ \\
\hline $\mathrm{KK}$ & $\mathrm{A}_{4}$ & - & $\mathrm{A}_{5}$ & $\mathrm{~A}_{6}$ \\
\hline
\end{tabular}

Keterangan:

1. $\mathrm{KE}$

2. $\mathrm{KK}$

3. $\mathrm{A}_{1}$

4. $\mathrm{A}_{2}$

5. $\mathrm{X}$

6. $\mathrm{A}_{3}$

7. A4

$8 . \quad-$

9. A5

10. A6
: Kelompok Eksperimen

: Kelompok Kontrol

Pre test Kelompok Eksperimen

Post test Kelompok Eksperimen

: Perlakuan (Intervensi)

Follow-Up Kelompok Eksperimen

: Pre test Kelompok Kontrol

: Tidak diberi Perlakuan (Intervensi)

: Post test Kelompok Kontrol

: Follow-Up Kelompok Kontrol 
Intervensi manajemen kelas terdiri dari beberapa tahapan diantaranya yaitu (1) preventif (2) active learning dan (3) korektif, (Afiif \& Idris (2016) serta Bank \& Eu, dalam Kumara, 2004). Secara umum intervensi ini bertujuan untuk membantu mewujudkan kondisi kelas yang kondusif dan mendorong siswa agar terlibat aktif pada setiap proses pembelajaran khususnya matematika, dengan sasaran utama adalah gangguan konsentrasi belajar matematika siswa akan menurun. Kegiatan preventif bertujuan untuk mengantisipasi munculnya suasana tidak kondusif diawal kegiatan belajar mengajar

Prosedur dalam kegiatan preventif dimaksudkan agar ruang kelas dan seisinya termasuk guru dan siswa sudah dalam keadaan yang benar-benar siap untuk memulai aktivitas belajar mengajar dengan tertib dan teratur. Active learning dimaksudkan untuk memudahkan guru dalam mengelola dan menyampaikan materi pelajaran agar siswa dapat berpartisipasi aktif dalam setiap proses pembelajaran dan tidak menjadikan guru sebagai satu-satunya sumber informasi sehingga siswa dapat lebih berkonsentrasi karena sudah lebih dominan terlibat dalam kegiatan belajar daripada melakukan hal-hal yang tidak ada hubungannya dengan pelajaran. Korektif bertujuan untuk mengelola sistem pembelajaran agar dapat terselenggara kegiatan belajar mengajar yang efisien dan produktif dimana guru dapat mengajar dengan efisien dan siswa dapat mengikuti proses pembelajaran tanpa adanya kebingungan ataupun hambatan. Prosedur dalam kegiatan korektif dimaksudkan agar tidak banyak waktu yang terbuang bagi siswa maupun guru untuk mengerjakan hal-hal lain yang tidak terkait pembelajaran ataupun membuang waktu untuk sekedar mencari solusi dari berbagai macam kebingungan dan hambatan yang terjadi saat proses pembelajaran.

Modul manajemen kelas ini diterapkan guru kepada siswa dalam pembelajaran matematika, sebelum menerapkan modul guru diberi pelatihan terlebih dahulu oleh seorang fasilitator. Materi modul manajemen kelas akan diberikan fasilitator dengan sesi briefing dan sharing, dimana pada tahap awal guru diberikan materi modul dan diberikan gambaran mengenai prosedur pelaksanaan intervensi. Setelah itu, fasilitator dan guru mendiskusikan hal-hal terkait relevansi isi dan prosedur modul saat diterapkan di kelas, sehingga dapat diperoleh kesimpulan mengenai prosedur manajemen kelas yang relevan untuk diterapkan disesuaikan dengan kebutuhan siswa, ketersediaan waktu dan alat serta kemampuan guru dalam menerapkan.

Intervensi manajemen kelas ini dilaksanakan selama 3 hari yakni tanggal 24, 25 dan 28 januari 2019 disesuaikan dengan jadwal dan durasi pelajaran matematika yang telah ditetapkan sekolah. Dimana untuk satu kali pertemuan, pelajaran matematika biasanya dilaksanakan dalam 2-3 jam pelajaran dan 1 jam pelajaran berdurasi 35 menit. Total waktu intervensi selama 3 hari kurang lebih 300 menit. Sebelum intervensi dilaksanakan kelompok eksperimen dan kelompok kontrol diberikan pretest, lalu setelah pelaksanaan intervensi masing-masing kelompok diberi posttest dan kemudian satu minggu setelah intervensi, kelompok eksperimen dan kelompok kontrol diberikan follow up. Intervensi manajemen kelas pada kelompok eksperimen dilakukan diruangan kelas VB lantai 2 SD Muhammadiyah Kandangsapi Surakarta.

Analisis data dalam penelitian ini dilakukan dengan menggunakan statistika parametrik dengan uji Paired Sample T-Test dan Independent sampel T-Test. Paired dan dan Independent Sample T-test digunakan untuk mengetahui pengaruh intervensi manajemen kelas terhadap penurunan gangguan konsentrasi belajar matematika siswa dan dipergunakan untuk melihat apakah penurunan gangguan konsentrasi belajar matematika pada kelompok eksperimen, signifikan. Selanjutnya perhitungan akan dilakukan dengan menggunakan bantuan SPSS (Statistical Packages for Social Science) Versi 24.0.

\section{HASIL DAN PEMBAHASAN}

Data dari 60 subjek dalam penelitian ini: kelompok eksperimen dan kelompok kontrol menunjukkan ada perbedaan signifikan antara pretest dan posttest pada kelompok eksperimen maupun kelompok kontrol. Hal ini menunjukkan bahwa skor gangguan konsentrasi belajar matematika saat pretest dan posttest pada masing-masing kelompok berbeda. Hasil analisis tersebut dapat dilihat pada tabel 2.

Tabel. 2 Statistik Deskriptif Kelompok Eksperimen dan Kontrol

\begin{tabular}{lllllll}
\hline $\begin{array}{l}\text { DataGangguan } \\
\text { Konsentrasi Belajar }\end{array}$ & Kelompok & N & Mean & SD & Max & Min \\
\hline \multirow{2}{*}{$\begin{array}{lllll}\text { Pretest } \\
\text { Postest }\end{array}$} & Eksperimen & 30 & 82.60 & 7.85 & 97 & 65 \\
\cline { 2 - 7 } & Kontrol & 30 & 88.60 & 6.03 & 97 & 73 \\
\hline & Eksperimen & 30 & 48.83 & 9.39 & 71 & 31 \\
\cline { 2 - 7 } & Kontrol & 30 & 87.90 & 6.17 & 99 & 75 \\
\hline
\end{tabular}

Hasil uji paired sample t-test pada kelompok eksperimen diperoleh nilai rata-rata pre-test sebesar 
82,60 dan nilai rata-rata post-test 48,83 yang menunjukkan adanya penurunan nilai rata-rata sebesar 33,77. Didapatkan juga t hitung $>\mathrm{t}$ tabel $(19,191>$ $0,639)$ dan pada taraf signifikansi $1 \% \mathrm{p}<0,01(0,000<$ $0,01)$ yang dapat disimpulkan bahwa ada penurunan gangguan konsentrasi belajar matematika yang signifikan pada kelompok eksperimen setelah diberi intervensi manajemen kelas. Sedangkan hasil uji paired t-test pada kelompok kontrol diperoleh nilai rata-rata pre-test sebesar 88,60 dan nilai rata-rata posttest 87,90 yang menunjukkan adanya penurunan nilai rata-rata sebesar 0,7 . Didapatkan juga t hitung $>\mathrm{t}$ tabel $(0,431>0,014)$ dan pada taraf signifikansi $1 \% \mathrm{p}>0,01$ $(0,670>0,01)$ yang berarti dapat disimpulkan bahwa tidak ada penurunan gangguan konsentrasi belajar matematika yang signifikan pada siswa kelompok kontrol.

Selanjutnya adalah hasil uji independent sample t-test untuk posttest diketahui nilai rata-rata pada kelompok eksperimen sebesar 48,83 dan nilai rata-rata pada kelompok kontrol sebesar 87,90 lebih besar dibandingkan kelompok eksperimen. Didapatkan pula nilai $\mathrm{p}<0,01(0.000<0,01)$. Dapat disimpulkan ada perbedaan yang signifikan dari skor gangguan konsentrasi belajar matematika siswa pada kelompok eksperimen dan kelompok kontrol, dimana kelompok eksperimen memiliki skor gangguan konsentrasi belajar matematika lebih rendah setelah diberi intervensi dan kelompok kontrol memiliki skor gangguan konsentrasi belajar matematika yang lebih tinggi karena tidak diberi intervensi. Hasil uji independent sample t-test kelompok eksperimen dan kelompok kontrol dapat dilihat pada tabel 3.

Tabel 3. Hasil Uji Komparatif (Independent Sample T Test) Eksperimen dan Kontrol

\begin{tabular}{llllll}
\hline Kelompok & $\begin{array}{l}\text { Mean } \\
\text { Pretest }\end{array}$ & $\begin{array}{l}\text { Mean } \\
\text { Posttset }\end{array}$ & Gain Skor & p & Kesimpulan \\
\hline Eksperimen & 82,60 & 48,83 & 33,76 & 0,00 & Signifikan \\
\hline Kontrol & 88,60 & 87,90 & 0,70 & 0,67 & Tidak Signifikan \\
\hline
\end{tabular}

Temuan lain dalam penelitian ini adalah hasil analisis postest - follow up kelompok eksperimen, dimana diperoleh nilai $\mathrm{p}>0,01(0,101>0,01)$ dan nilai rata-rata posttest yaitu 48,83 sedangkan nilai rata-rata pada saat follow up yaitu 46,93. Berdasarkan nilai statistik yang telah dipaparkan diatas dapat disimpulkan bahwa tidak ada perbedaan yang signifikan dari nilai rata-rata antara posttest dan follow up pada kelompok eksperimen. Hal tersebut menunjukkan bahwa efek intervensi manajemen kelas pada kelompok eksperimen masih dapat bertahan.

Efek yang dirasakan siswa setelah mengikuti kegiatan belajar mengajar dengan manajemen kelas yaitu gangguan konsentrasi belajar matematika siswa menurun karena saat ini belajar matematika itu menyenangkan dan tidak membosankan. Durasi belajar matematika yang cukup lama dan intensitas tatap muka yang hampir setiap hari dilakukan tidak membuat siswa merasa lelah dan stress karena kegiatan mengerjakan soal-soal hitungan yang dilakukan dengan role play menjadi lebih mudah dan menyenangkan namun tetap menantang.

Berdasarkan hasil uji hipotesis yang dilakukan dapat disimpulkan bahwa intervensi manajemen kelas efektif untuk menurunkan gangguan konsentrasi belajar matematika pada siswa SD Muhammadiyah 4 Kandangsapi Surakarta. Dengan demikian, hipotesis yang diasumsikan oleh peneliti dinyatakan dapat diterima.

Pfiffner (2011) menjelaskan bahwa diantara faktor-faktor yang dapat mempengaruhi konsentrasi belajar siswa adalah hubungan positif antara guru dan siswa, teknik manajemen kelas dan pengaturan fisik fasilitas belajar. Lebih lanjut Pfiffner juga mengatakan kemampuan guru untuk memanajemen kelas teramat dibutuhkan dalam mewujudkan kondisi kelas yang terkendali sehingga siswa tidak terganggu konsentrasi belajarnya. Mehralizadeh, Ghorbani, Zolfaghari, Shahinfar, Nikkhah \& Pourazizi (2013) dalam penelitiannya menjelaskan bahwa diantara faktor-faktor yang mempengaruhi konsentrasi belajar siswa adalah faktor eksternal yakni pengelolaan penyampaian materi belajar yang konsisten dan manajemen kelas.

Pada berbagai penelitian, intervensi manajemen kelas terbukti efektif mengatasi berbagai permasalahan dalam belajar diantarnya seperti peneiltian yang dilakukan Hung \& Fang (2014) menunjukkan bahwa manajemen kelas dapat meningkatkan motivasi belajar siswa. Penelitian Khofifah (2016) \& Sari (2016) menunjukkan bahwa manajemen kelas dapat meningkatkan prestasi dan hasil belajar. Sedangkan penelitian Pratiwi (2017) menunjukkan bahwa manajemen kelas berpengaruh positif terhadap keaktifan belajar siswa. Berikutnya adalah hasil penelitian Munawwaroh (2018) yang menunjukkan ada pengaruh manajemen kelas terhadap kedisiplinan belajar.

Menurut Brophy (2006), Doyle (1990), Emmer \& Evertson (1991) dalam buku yang ditulis Ormrod berjudul Educational Psychology Developing Learners (2008) manajemen kelas yang efektif perlu melibatkan siswa secara aktif dan produktif dalam setiap proses pembelajaran sehingga pembelajaran berbasis active learning dapat lebih dominan terjadi di 
kelas dan akan mengurangi perilaku mengganggu siswa yang dapat menjadikan suasana belajar tidak kondusif dan menghambat tujuan pembelajaran.

Menurut Jones \& Louise (2012) manajemen kelas merupakan sebuah sistem di dalam kelas yang tidak terbatas hanya pada intervensi guru dalam mendisiplinkan kelas tetapi juga sebuah sistem yang dirancang untuk memaksimalkan keterlibatan siswa dalam aktivitas belajar mengajar. Di dalam intervensi manajemen kelas terdapat metode pembelajaran active learning yang menurut Muijs \& Reynolds (1999) metode pembelajaran ini sesuai untuk diterapkan di kelas-kelas dengan situasi pembelajaran yang tidak kondusif yang mengganggu konsentrasi belajar siswa. Dimana pembelajaran berbasis active learning ini menuntut siswa untuk terlibat aktif dan produktif dalam proses belajar mengajar sehingga dalam pelaksanaannya, siswa akan dibiasakan untuk mandiri dan tidak menjadikan guru sebagai satu-satunya sumber informasi.

Metode pembelajaran active learning dapat dijadikan sebagai salah satu strategi yang dapat membantu siswa menurunkan gangguan konsentrasi belajar yang timbul akibat dari stres siswa menghadapi pelajaran yang dianggap sulit, salah satunya matematika. Menurut Kumara (2004) dengan metode active learning, siswa akan lebih banyak dilibatkan dalam proses pembelajaran sehingga siswa pun akan terbiasa untuk memahami materi, mengerjakan soalsoal, berdiskusi dan menghadapi berbagai kesulitan dan tantangan dalam pelajaran matematika. Meskipun siswa tidak menyukai dan memiliki pandangan yang negatif terhadap pelajaran ini, mau tidak mau, suka tidak suka, mereka harus tetap terlibat aktif dalam setiap proses pembelajarannya sehingga, seiring berjalannya waktu siswa pun akan terbiasa dan bahkan merasa nyaman untuk bergelut dengan pelajaran matematika.

Terdapat beberapa kelebihan intervensi manajemen kelas diantaranya, memiliki tahapan yang mencakup keseluruhan komponen di kelas baik dari segi pengelolaan fisik kelas maupun dari segi pengelolaan metode pembelajarannya, dimana keduanya termanifestasi dalam tiga tahapan yakni preventif, active learning dan korektif. Ketiga tahap ini secara umum bertujuan untuk mempersiapkan kelas dalam kondisi kondusif dan siap dipergunakan dalam kegiatan belajar mengajar, mengefektifkan kegiatan belajar mengajar dengan melibatkan siswa secara aktif dan produktif dalam setiap proses pembelajaran serta mengelola sistem pembelajaran agar dapat terselenggara kegiatan belajar mengajar yang efisien dan produktif dimana guru dapat mengajar dengan efisien dan siswa dapat mengikuti proses pembelajaran tanpa adanya kebingungan ataupun hambatan.

Tahap active learning meliputi concept analysis model, the experiential learning dan the group inquir, intinya adalah untuk membantu meningkatkan konsentrasi belajar matematika siswa dengan cara dilibatkan secara aktif dalam setiap proses pembelajaran agar siswa lebih aktif dan produktif dalam proses pemerolehan informasi dan pengetahuan sehingga peluang siswa untuk melakukan hal-hal lain diluar pembelajaran matematika dapat diminimalisir atau bahkan dihilangkan. Penerapan active learning dalam pembelajaran matematika juga dimaksudkan untuk mengubah pandangan negatif siswa pada pelajaran ini dengan asumsi bahwa jika pembelajaran matematika dirancang dengan metode dan media belajar yang variatif maka siswa distimulasi untuk menikmati pelajaran ini dengan pelaksanaan pembelajaran yang lebih mudah dan menyenangkan. Sedangkan tahap preventif dan korektif bertujuan untuk memastikan bahwa setiap proses yang dilakukan dalam kegiatan belajar mengajar khususnya matematika, dapat berjalan dengan tertib dan lancar mulai dari awal sampai akhir. Adapun berbagai permasalahan yang dihadapi selama berlangsungnya proses belajar mengajar dan tidak terdeteksi diawal maka akan sesegera mungkin ditindaklanjuti agar tidak mengganggu proses belajar mengajar secara keseluruhan.

Secara umum intervensi manajemen kelas yang dilaksanakan selama 3 hari dapat berjalan dengan lancar dan tertib mulai dari awal sampai akhir pembelajaran. Seluruh siswa di kelas aktif terlibat dalam setiap proses belajar mengajar, diantaranya aktif mengajukan pertanyaan bahkan terdapat beberapa siswa yang sampai maju ke meja guru sambil membawa bukunya untuk bertanya, siswa kooperatif saat ditunjuk secara bergiliran untuk mengerjakan soalsoal dipapan tulis, tertib saat dilakukan pembagian dan diberikan tugas dalam kelompok, tugas-tugas dikerjakan sampai tuntas dan siswa aktif mengkritisi jawaban yang dituliskan teman ataupun guru sehingga setiap pembahasan soal selalu terjadi diskusi yang sengit.

Intervensi manajemen kelas terbukti dapat menurunkan gangguan konsentrasi belajar matematika siswa juga terlihat dari hasil evaluasi kualitatif yang diperoleh dari hasil wawancara kepada siswa maupun guru. Kesesuaian materi, tahapan dan prosedur dalam modul dengan RPP (Rencana Pelaksanaan Pembelajaran) menjadikan intervensi ini dilakukan tanpa merubah proses belajar mengajar di kelas dari segi jadwal pelajaran, durasi belajar dan kesesuaian materi. Adapun modifikasi yang dilakukan seperti setting kelas, penegakkan aturan, pengelolaan metode dan media pembelajaran serta pemberian reward dan punishment pada siswa sudah sesuai dengan tujuan yang ingin dicapai. Cara guru menerapkan isi modul sudah memadai dan berhasil membuat siswa-siswa berantusias dan memberikan respon yang baik pada setiap tahapan intervensi yang termanifestasi dalam kegiatan belajar mengajar di kelas, meskipun pada awal penerapan intervensi banyak siswa yang bingung dan merasa ada sesuatu yang berbeda pada proses belajar mengajar khususnya pada pelajaran matematika namun siswa menyatakan bahwa tidak butuh waktu lama bagi mereka untuk dapat menikmati metode dan media belajar yang baru-baru ini diterapkan.

Kekhasan yang muncul dari penelitian ini yaitu, adanya role play dalam intervensi sebagai salah satu metode active learning. Metode role play yang 
diterapkan dalam proses pembelajaran matematika direspon positif dan membuat siswa lebih tertarik untuk belajar daripada melakukan hal lain diluar kegiatan belajar. Metode role play ini juga yang mendorong keaktifan siswa saat pembelajaran matematika dan meminimalisir peluang terganggunya konsentrasi belajar siswa sehingga dapat dikatakan bahwa metode role play dalam intervensi manajemen kelas menjadi salah satu kontribusi yang besar untuk menurunkan gangguan konsentrasi belajar matematika siswa.

Variasi dalam penggunaan media pembelajaran dapat mencegah timbulnya suasana belajar monoton pada siswa yang usianya tergolong rentan mengalami kejenuhan yang berujung pada terganggunya konsentrasi belajar. Metode role play akan lebih intens diterapkan karena sangat membantu siswa dalam memahami materi maupun saat mengerjakan soal, penggunaan media pembelajaran yang konkrit sangat sesuai dengan tahap perkembangan kognitif siswa SD usia 9-12 tahun yang sedang dalam tahap berpikir konkrit.

\section{SIMPULAN}

Penelitian ini menemukan bahwa ada perbedaan gangguan konsentrasi belajar matematika antara kelompok yang diberikan intervensi dengan kelompok yang tidak diberikan intervensi. Kelompok yang diberikan intervensi memiliki gangguan konsentrasi belajar matematika yang lebih rendah daripada kelompok yang tidak diberikan intervensi, sehingga dapat dikatakan intervensi manajemen kelas efektif untuk menurunkan gangguan konsentrasi belajar matematika pada siswa SD Muhammadiyah 4 Kandangsapi Surakarta.

Saran untuk pihak sekolah adalah sebagai berikut: (1) diharapkan memberikan waktu dan ijin kepada peneliti untuk memberikan pelatihan manajemen kelas kepada guru-guru. (2) Sekolah dapat menyediakan fasilitas media pembelajaran untuk mendukung proses pembelajaran menjadi lebih mudah dan menyenangkan terutama pada mata pelajaran yang dianggap sulit bagi siswa, salah satunya matematika. Saran untuk Siswa (1) Sekiranya serius dan sungguhsungguh saat mengikuti proses belajar mengajar serta mengurangi perilaku yang dapat merugikan diri sendiri dan menggaggu kondisifitas belajar di kelas. (2) Lebih aktif dalam setiap proses pembelajaran, seperti membaca materi, latihan mengerjakan soal dll, aktivitas tsb dapat meminimalisir peluang siswa berfokus pada hal lain diluar pelajaran matematika. (3) Ubah mindset bahwa pelajaran matematika sulit dan menakutkan, coba kenali dulu materinya, nikmati setiap prosesnya dan dapatkan manfaatnya. Saran untuk guru adalah: (1) Konsisten menerapkan manajemen kelas khususnya metode active learning agar konsentrasi siswa pada pembelajaran matematika minimal dapat bertahan atau bahkan meningkat. (2) Mendukung dan memotivasi siswa untuk aktif pada setiap proses belajar mengajar.

\section{DAFTAR PUSTAKA}

Afif, A., \& Idris, R. (2016). Pengaruh implementasi manajemen kelas terhadap perilaku belajar mahasiswa pada jurusan manajemen pendidikan islam fakultas tarbiyah dan keguruan UIN ALAUDDIN makassar. Lentera Pendidikan 19 (2), 135-136.

Anderson, A., Hamilton, R. J., \& Hattie, J. (2004). Classroom climate and motivated behavior in secondary schools. Journal Teaching and Learning University of Auckland 7 (3), 217220.

Arikunto, S. (2000). Pengelolaan Kelas dan Siswa. Pekanbaru: Rajawali Pers.

Barkley, R. (2006). Handbook attention deficit hyperactivity disorder (ed. 3). London: The Guilford Press.

Chyquitita, T., Winardi, Y., \& Hidayat, D. (2018). Pengaruh brain gym terhadap konsentrasi belajar siswa kelas XI IPA dalam pembelajaran matematika di SMA XYZ Tanggerang. A journal of Laguage 14 (1), 40.

Feldman, W. (2002). Mengatasi gangguan belajar pada anak. Jakarta: Prestasi Pustaka Publisher.

Ghozali, I. (2006). Aplikasi analisis multivariate dengan program SPSS. Semarang: Badan Penerbit Universitas Diponegoro.

Good, T., \& Brophy, J. (1991). Looking in classrooms (ed. 5). New York: Harper Collins Publishers.

Hakim, T. (2003). Mengatasi gangguan konsentrasi. Jakarta: Puspa Swara.

Hatiningsih, N. (2013). Play therapy untuk meningkatkan konsentrasi pada anak attention deficit hyperactiviti disorder (ADHD). Jurnal Ilmia Psikologi Terapan 1 (2), 336-340.

Hung, C.-L., \& Fang, C.-C. (2014). Perceived Classroom Management and Student Learning Motivation In Social Studies Of Taiwan Junior High School Students. European Journal of Research in Social Sciences Vol. 2 No. 3, 47-50.

Jones, V., \& Louise. (2012). Manajemen kelas komperhensif. Jakarta: Kencana.

Kamil, B., \& Olvatika, Y. P. (2015). Konseling Behavioral dalam Meningkatkan Konsentarsi Belajar Peserta Didik Sekolah Menegah Pertama Negeri 1 Hulu Sungkai Kabupaten Lampung Utara. Jurnal Bimbingan dan Konseling Vol. 2 No. 1, 19-20. 
Khofifah, N. (2016). Pengaruh Manajemen Kelas Dan Keaktifan Belajar Terhadap Prestasi Belajar Siswa Sekolah Dasar. Publikasi Ilmiah.

Kumara, A. (2004). Model pembelajaran "active learning" mata pelajaran sains singkat SD kota Yogyakarta sebagai upaya peningkatan "life skills". Jurnal Psikologi 1 (2), 65,68-69.

Mehralizadeh, S., Ghorbani, R., Zolfaghari, S., Shahinfar, H., Nikkhah, R., \& Pourazizi, M. (2013). Factors affecting student concentration in classroom: medical. Iranian Journal of Medical Education 13 (8), 671.

Mulyana, O. P., \& Izzati, U. A. (2013). Penerapan Relaksasi Atensi Untuk Meningkatkan Konsentrasi Belajar pada Siswa SMK. Jurnal Psikologi : Teori dan Terapan.

Munawaroh, L. (2018). Pengaruh Pengelolaan Kelas Terhadap Disiplin Belajar Siswa Kelas V Sekolah Dasar Se-Gugus I Upt Kecamatan Pundong Kabupaten Bantul. Skripsi (Tidak diterbitkan).

Omrod, J. (2009). Psikologi Pendidikan Membantu Siswa Tumbuh dan Berkembang Edisi ke enam. Jakarta: Penerbit Erlangga.

Ormrod, J. E. (2008). Educational Pshychology: Developing Learners. New Jersey: Prentice Hall.

Pfiffner, L. J. (2011). All about ADHD: The complete practical guide for classroom teachers (ed. 2). New York: Scholastic.
Piaget. (1972). Teori Perkembangan Kognitif Jean Piaget Terjemahan Oleh Dr. Paul Suparno. Yogyakarta: Pustaka Pelajar.

Pratiwi, Y. (2017). Pengaruh Manajemen Kelas Terhadap Hasil Belajar Siswa Di Sekolah Menengah Pertama Negeri 1 Pedamaran Ogan Komering Ilir. Skripsi (Tidak diterbitkan).

Purwanto, \& Nuryana. (2010). Efektivitas Brain Gym Dalam Meningkatkan Konsentrasi Belajar Pada Anak. Jurnal Ilmiah Berkala Psikologi Vol. 12 No. 1, 95-97.

Ramadhani, H. S., Lestiawati, E., \& Wahyuningsih, M. (2016). Pengaruh terapi bermain puzzle terhadap konsentrasi belajar anak kelas I di SD negeri pokoh I Ngemplak, Sleman, D.I Yogyakarta. Jurnal Medika Respati 11 (4), 40-42.

Sari, A. O. (2016). Pengaruh Pengelolaan Kelas Dalam Pembelajaran Aqidah Akhlak Terhadap Etika Belajar Siswa Kelas VII Di Madrasah Tsanawiah Tuan Sokalangu Gabus Pati Tahun Pelajaran 2015/2016. Skripsi.

Siregar, N. R. (2018). Persepsi siswa pada pelajaran matematika: studi pendahuluan pada siswa yang menyenangi game. Prosiding Teтu Ilmiah X Ikatan Psikologi Perkembangan Indonesia. Diakses dari http://jurnal.unissula.ac.id/index.php/ippi/arti cle/view/2193. 